\section{VALUE PROPOSITION DESIGN}

Kasifatul Kurubiyah - 2440004142

UNIVERSITAS BINA NUSANTARA

kasifatul.kurubiyahebinus.ac.id
Content: Canvas, Design, Test, Evolve Referensi

(Alexander Osterwalder, Yves Pigneur, Greg Bernarda \& Alan Smith(2014) Value

Proposition Design, John Wiley \& Sons, Inc.) Supervisor: Agung Purnomo

\title{
VALUE PROPOSITION DESIGN
}

- What to Test

- Testing Step-by-Step

- Experimenting Library

- Bringing It All Together
- Prototyping Possibilities

- Starting Points

- Understanding Customers

- Making Choices

- Finding the Right Business Model

- Designing in Established Organizations

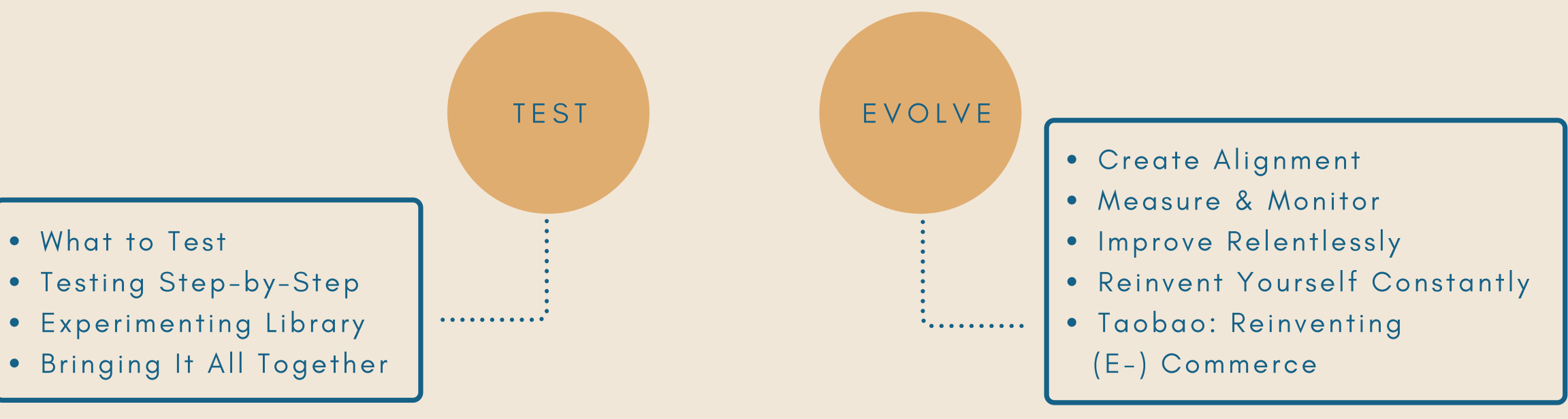

